DOI: https://doi.org/10.31933/dijemss.v2i4

Received: $10^{\text {th }}$ March 2021, Revised: $10^{\text {th }}$ February 2021, Publish: $25^{\text {th }}$ April 2021

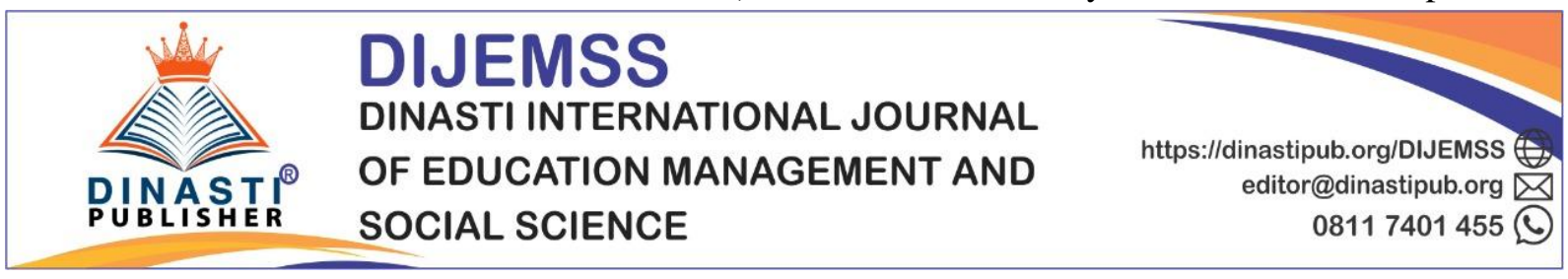

\title{
MANAGEMENT STRATEGY IN THE PROCESS OF DEVELOPING HUMAN RESOURCES IN THE COVID-19 PANDEMIC (CASE STUDY: PT. PAN BROTHERS, TBK)
}

\author{
Yuni Tanti Seven Purba ${ }^{1}$, Nani Ariani ${ }^{2}$, Mahendro Sumardjo ${ }^{3}$ \\ 1) Magister Manajemen, UPN Veteran Jakarta, yunitantiseven@ gmail.com \\ 2) Magister Manajemen, UPN Veteran Jakarta, nani.upnvj@gmail.com \\ ${ }^{3)}$ Magister Manajemen, UPN Veteran Jakarta, msumardjo@yahoo.com
}

Corresponding Author: Yuni Tanti Seven Purba ${ }^{1}$

Abstrack:This study contains the company management strategy of PT Pan Brothers, Tbk in the process of developing human resources during the COVID-19 pandemic. The process of developing human resources during a pandemic is carried out by the company thats like recruitment, training, controlling, performance appraisal and evaluation without layoffs. This research method uses qualitative research methods with a case study approach. This study uses primary data obtained directly from informants namely assistant company managers, company labor unions and HR consultants. The results showed that implementation of the human resource development process carried out by companies during the pandemic was not much different from the development of human resources before the pandemic, only the process mechanism was different. The company provides applications or systems to facilitate the process of developing human resources during the COVID-19 pandemic by utilizing technology in the industrial revolution 4.0. Researchers also found that during the pandemic, employee loyalty was needed as mentioned by Malayu and Armstrong so that an integrated relationship was created between the company and employees in the process of developing human resources.

Keywords: Management Strategy, Human Resource Development, Industrial Revolution 4.0, Pandemic COVID-19, PT Pan Brothers, Tbk

\section{INTRODUCTION}

The era of globalization has rolled on which is marked by the development of technology and the fast flow of information. Globalization brings many positive impacts as well as changes to aspects of human life and can create new problems in various sectors such as the labor sector. The development of globalization is often referred to as the Industrial Revolution Era 4.0. In the era of the industrial revolution 4.0, there were many transformation challenges in the labor sector so that all parties had to anticipate them. Workers as human resources in the era of the 4.0 industrial revolution must be able to face and adapt to various 
challenges of labor transformation. Currently, Indonesia is a developing country, as a developing country, of course, Indonesia has a dream to become a developed country. In order to support the progress of a country, it is necessary to improve the economy and Indonesia must be able to keep up with the times by increasing and improving human resources (HR).

At the end of December 2019 the world was shocked by the Corona Virus Disease (COVID-19) where the emergence of this virus originated in China, namely the city of Wuhan and Indonesia was also affected by the spread of this virus in March, Mr. President of Indonesia Joko Widodo announced that Indonesia had contracted the virus COVID-19. The result of this virus is crippling all sectors of the economy and types of jobs in Indonesia to varying degrees of severity. So that many companies in Indonesia are not able to survive and choose to close their companies, lay off their employees and even terminate their work relations. Therefore, the COVID-19 pandemic has forced many companies to change their business strategies in order to maintain their business continuity, so company leaders have started to set new management strategies or maintain existing strategies while maximizing human resources so that they can survive in the midst of an unknown pandemic situation. when will it end so that the Human Resources department must take an additional role to think about the effectiveness of HR in order to remain productive and able to compete for the progress of the company and maintain the company's existence.

Meanwhile, during this pandemic, the company PT Pan Brothers, Tbk was able to survive in this difficult situation and even the company was able to open new jobs and did not layoffs. This is because the company is looking for business opportunities in this difficult situation where the company's management has an idea to change its business strategy by producing personal protective equipment (PPE), hazmat and masks which during the pandemic are very much needed by the community and are able to export. This strategic step requires the company to add divisions or Core Business as part of a management strategy in order to achieve maximum goals. So that companies must develop human resources to improve employee skills to quickly adapt to pandemic conditions and companies must focus on developing effective and efficient work talent. Based on the background that occurred, this study wanted to know the management strategy developed by the company PT. Pan Brothers, Tbk to maintain and develop human resources for the continuity of the company and to know the management of human resource management policies in the era of the industrial revolution 4.0 at the time of the COVID-19 pandemic which is still happening today.

\section{LITERATURE REVIEW}

\section{Human Resource Development}

Human resource development is a process that changes individual behavior or prepares individuals to increase their knowledge, abilities, skills and so on in order to level up. This is done so that these human resources are able to work well according to the expectations of the organization (Mahendro Sumardjo \& Priansa, 2018).

HR development is part of training and development according to the explanation that "the highlight is the importance of HRM is to have training and development in the context of current management". Both of these approaches serve as benchmarks to see skills that are not only needed at that time but also for the future in line with the explanation of development of personnel relate with the identification of the necessary long-term capabilities that result from the company's strategic plan (Machado, 2018). 
The difference between development and training is that development refers to the educational process, work experience and relationships between employees as an effort to prepare future skills while training refers to the process of helping employees' performance in their current work (Machado, 2018). Therefore, the researcher examines several theories that explain the human resource development process as follows:

1) Malayu Hasibuan's Human Resources Development Method Malayu (Hasibuan, 2016) takes an approach regarding human resource development through management functions as follows:
a. Planning
b. Organizing
c. Briefing
d. Control
e. Procurement
f. Development
g. Compensation
h. Integration
i. Maintenance
j. Discipline
k.Termination

2) Benjamin et al.'s Human Resources Development Method

Benjamin, dkk (Bukit et al., 2017) argues that human resource development is carried out based on the following competency bases as follows:
a. Recruitment and Selection
b. Training and Development
c. Performance Management
d. Reward Management
e. Career Management

3) Prof. Dr. Wibowo's Human Resources Development Method

Wibowo (Prof. Dr. Wibowo, 2017) disclosed that human resource development is carried out with a development approach at the office (job-site) and outside the office (off-site) as follows:

1. Methods for developing human resources in the office (job-site) such as:
a. Training
b. Training
c. Job rotation

2. Methods for developing human resources outside the office (off-site) such as:
a. Courses and lectures
b. Simulation
c. Human relations training
d. Role playing
e. Sabbatical

4) Armstrong \& Taylor's Human Resources Development Method 
Armstrong \& Taylor (M.; T. Armstrong, 2014) argues that human resource development requires a strategic HR role as follows:
a. Organization
b. People Resourcing
c. Learning and Development
d. Reward Management
e. Employee Relations

Amstrong and Taylor (M.; T. Armstrong, 2014) also explained that "strategic resourcing is essentially about the integration of business and employees resourcing strategies so that the latter contribute to the achievement of the former" means that HR development can be seen in performance management, namely an integrated strategic approach to provide sustainable success for the organization as a team and individually. Almost Integration within the organization and create higher levels of shared ownership and commitment.

Performance management must be connected with other main processes such as business strategy, employee development, and total quality management, so it is integrated into 4 parts, namely:

1. Vertical integration

2. Functional integration

3. Integration needs

4. HR Integration
: part of balancing business, individual and team goals.

: linking the functional strategy across the business.

: individual with people in the organization as far as possible

: connecting various elements of human resource management to achieve desires between organizational management and individuals in line with organizational development, human resource development such as giving awards to these individuals.

Based on the study according to Malayu and Amastrong, it is stated that in the process of developing human resources there is an integration needed where Horizontal Integration means aligning performance management strategies with other HR strategies related to assessing, paying for, involving, and developing people, meanwhile, Vertical Integration is achieved with business strategies and a business plan through agreed team and individual goals to support the achievement of company goals. Forms of interrelated goals from the company level to the functional unit or team level and the individual level. A strategic step needs to be decided upon to ensure that these goals align into a cascading process so that the goals flow down from the top and at each level or the individual is able to clearly define the higher level goals. Organizations provide opportunities for both individuals and teams to define their own goals within a framework that is defined according to the goals and requirements of the organization. So that an open conversation takes place between superiors and subordinates according to mutually agreed goals.

The importance of integration in personnel management, as a form of uniting the desires of employees with the interests of the company. This means that employees can meet their needs and the company gets high profits so that an atmosphere of good cooperation is created and provides satisfaction to both parties. Integration is carried out based on human relationships, motivation, leadership, agreement, cooperation, and Collective Bargaining (Mu'ah, 2017). 


\section{Human Resource Development in the 4.0 era}

According to the Ministry of Communication and Information Technology of the Republic of Indonesia, the industrial revolution 4.0 is a condition that combines several technologies such as cyber technology and automation technology and is usually referred to as "cyber physical system", so that in the end a work environment becomes more effective and efficient. In the industrial sector, this situation will have an impact on the quality of human resources work and organizational production expenditures. The industrial revolution 4.0 provides a very fast change to create a better quality of life, marked by the emergence of advanced technology, smart robots, and driverless vehicles that allow humans to maximize brain function.

The industrial revolution 4.0 will also more or less change industrial work patterns and job characteristics, creating new types of businesses, new jobs and new professions. The application of digital information systems is used to all parts of the work which will reduce the role of humans and turn into a recording system with a computer.

The implementation of the 4.0 industrial revolution, it is hoped that companies will adjust the implementation of business processes with jobs that are more challenging and responsible and avoid routine tasks, especially for millennials. In addition, flexibility is required in work and a salary that is proportional to the employee's efforts so that it will affect the mindset of HR who must continue to hone performance to improve quality in order to survive and be able to competion (Schaar et al., 2019).

\section{CONCEPTUAL FRAMEWORK}

Based on the research boundaries of Management Strategy in the Human Resource Development Process during the Covid-19 Pandemic (Case Study: Pt. Pan Brothers, Tbk), the framework is as follows:

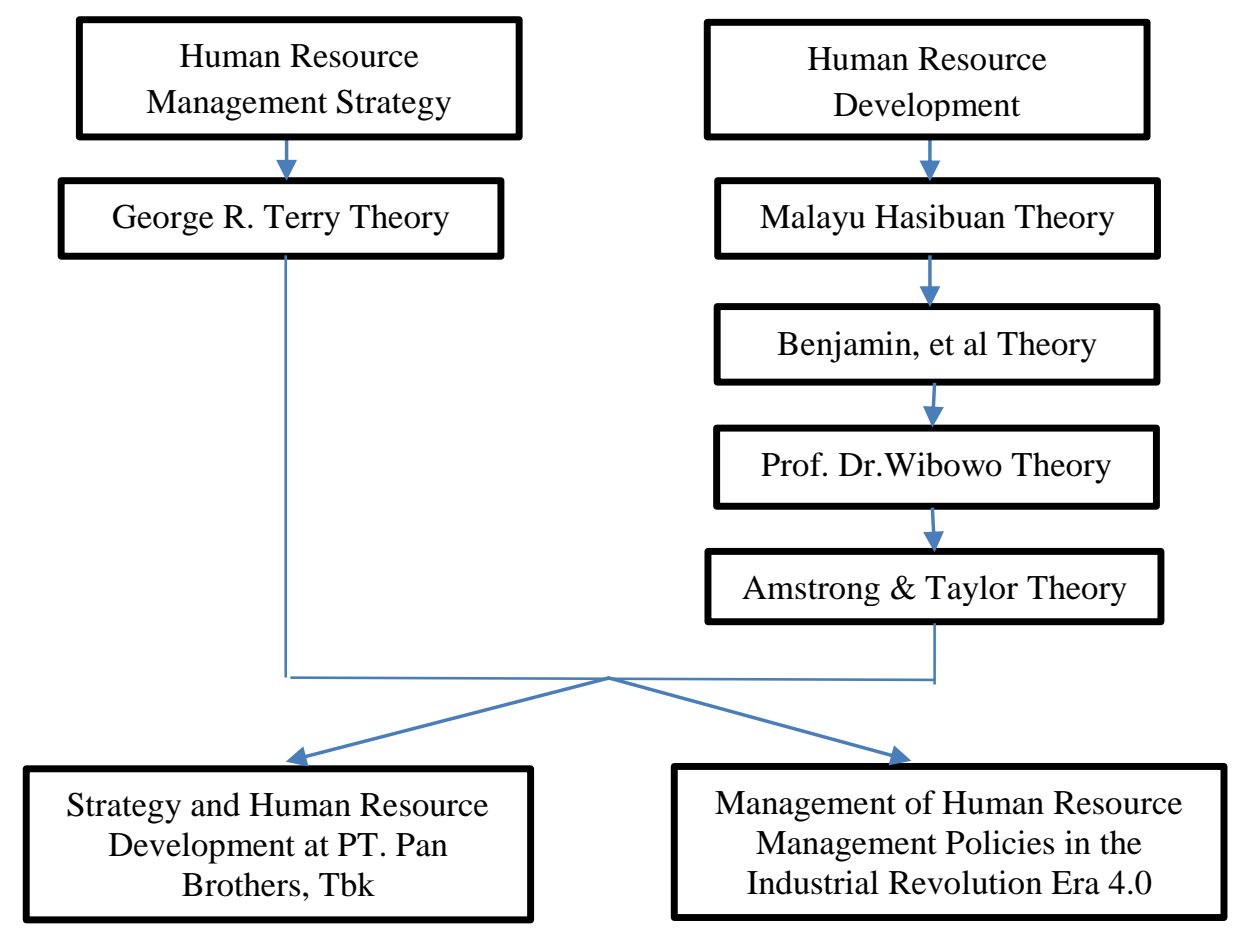




\section{RESEARCH METHODS}

his research method uses qualitative research methods with a case study approach. Qualitative research is research that uses analytical procedures to build views in detail, in the form of words or text, meaning that qualitative does not use statistical or numerical analysis procedures (Moleong, 2017).

Data collection techniques in this study are: observation, literature study, documentation, interviews, recording. Research subjects who are used as sources of information or informants needed in collecting research data by interviewing 3 informants, namely:

Interview Subject

\begin{tabular}{|c|l|c|c|}
\hline No & \multicolumn{1}{|c|}{ Subjek } & Jenis Kelamin & Profesi \\
\hline 1. & Mr. Prasetyo & Male & Assistant manager HRD \\
\hline 2. & Mr. Joko & Male & Secretary Serikat Pekerja \\
\hline 3. & Mr. Denny & Male & Consultant People Development \\
\hline
\end{tabular}

Source: Researcher

\section{RESULTS AND DISCUSSION}

The COVID-19 pandemic has clearly worsened Indonesia's health system and economy, various sectors were forced to change the company's business processes and also the process of developing human resources in these companies, especially the company PT Pan Brothers, Tbk. Based on electronic media reading, even though the company was slightly affected by the COVID-19 pandemic, the company did not layoffs and only took steps to change the process of developing its human resources.

The reason PT Pan Brothers, Tbk recruited thousands of employees to catch up with the high demand for health needs is so that the company is able to survive the difficult situation during this pandemic. The need for human resources has made the company not take layoffs but rather develop human resources who have worked in the company to be able to adapt quickly to changes in the company's business. Employees who worked at the PT Pan Brothers, Tbk company before the pandemic, the company produced ready-to-wear clothes such as shirts, jackets, t-shirts, pants and others, while after the pandemic the company switched to producing PPE, hazmat and masks. This certainly changes the way human resources work in the company, especially employees in the production sector. Employees must change their work habits due to urgent situations and are asked to quickly learn and develop their skills through the help of company management. The production of clothing is certainly different from the production of PPE, hazmat and masks because during this pandemic the production quality of PPE, hazmat and masks must be of higher quality so that the production results become anti-COVID-19 virus. So that users of PPE, hazmat and masks can be comfortable wearing them without any worries.

This strategic step is a great opportunity for the company to make maximum use of existing human resources without reducing employees. So that the addition of employees is very beneficial for the company to remain sustainable and human resources who are in dire need of work during this pandemic.

The process of developing human resources at the PT Pan Brothers, Tbk company during the COVID-19 pandemic included recruitment, training, supervision, performance appraisal, and evaluation without executing the employee dismissal process. The management strategies in developing human resources during the pandemic as follows: 
a) Recruitment by taking employees who have been laid off or transferred to areas affected by the COVID-19 pandemic from similar companies.

b) Training by making in-class training with a small capacity and complying with health protocols, virtual training and maximizing internal trainers and division heads being trained as trainers.

c) Supervision using a system such as the balance score card system as an application and installed in each management division.

d) Performance Appraisal by utilizing an application performance system on each employee's computer, especially for employees at the top and middle management levels.

e) Evaluation by conducting routine evaluations every day, every month, trimester, semester or yearly.

Meanwhile, management of management policies in human resource development entered the Revolutionary Era 4.0 during the pandemic as follows:

a) Creating an MDP (Management Development Program) program, which is the recruitment of employees with a maximum age of 25 years.

b) Recruitment such as a $100 \%$ online psychological test and $90 \%$ virtual interviews with video calls.

c) Virtual training and e-learning based training.

d) Supervision through digitalization of HR such as attendance, requests for leave, permits, booking official trips, and booking vehicles.

Policy management entering the revolutionary era 4.0 by utilizing technology provided by the company is used evenly by every employee at PT Pan Brother, Tbk. The difference in the use of technology before the pandemic is not too different because PT Pan Brother, Tbk is a company that uses a lot of machines so that production work also depends on technology. Meanwhile, during this pandemic, the use of technology was increasingly being improved, especially to maintain distance and reduce crowds. Performance appraisers have a significant impact, employees are required to provide good performance to get compensation so that employees compete to be more competitive and innovate at work. In addition, performance appraisals can also determine the skills possessed by each employee.

The researcher argues and assesses that the management strategy of PT Pan Brothers, Tbk in the process of developing human resources during the COVID-19 pandemic tends to be in accordance with the theory put forward by Benjamin, et al which states that the competency-based HR development process and Armstrong and Taylor stated that the process HR development requires the role of HR to regulate the stages. While during the pandemic, employee loyalty is required as mentioned by Malayu and Armstrong where companies are asked to commit to providing comfort and instilling spiritual values to employees to create good cooperative relationships between top, middle, and low levels so that the company remains sustainable and does not overlap so that there is no parties who feel aggrieved.

It can be concluded that the human resource development strategy during the pandemic that was implemented by PT. Pan Brothers, Tbk is the right step. During normal times, the supervision and performance appraisal stages are indeed more effective and efficient using technology. However, recruitment and training during a pandemic tends to be less effective if applied during normal conditions. Because it is necessary to directly assess human expressions, facial expressions, and gestures. 


\section{CONCLUSION}

Based on the findings, analysis, and discussion of this research, several conclusions can be drawn as follows:

1) The process of developing human resources at PT Pan Brothers, Tbk during the COVID19 pandemic includes recruitment, training, supervision, performance appraisal, and evaluation without terminating employees.

a) At the recruitment stage, the management strategy in developing human resources is to take employees from other similar companies where the company has closed or moved to an area affected by the COVID-19 pandemic.

b) At the training stage, the management strategy in developing human resources is to implement training by creating a class of about 10 people by adhering to health protocols or implementing virtual training using technological means. In addition, the company also does not use external trainer services and uses division heads as trainers.

c) At the monitoring stage, the management strategy in developing human resources is to use a system that has been provided by management, namely the balance score card system as a performance monitoring application and has been distributed and used in each division of the company.

d) At the performance appraisal stage, the management strategy in developing human resources is to utilize the performance appraisal application system installed on each employee's computer. This strategy makes it easier for employees to find out their performance every month more quickly and be able to carry out the evaluation process for their next performance.

e) At the evaluation stage, the management strategy in human resource development is to carry out routine evaluations of the entire human resource development process determined by the company to be considered in the future.

2) PT Pan Brothers, Tbk has started to take advantage of the moment of the industrial revolution 4.0 in its business processes. The management of human resource management policies in the face of the industrial revolution 4.0 by PT Pan Brothers, Tbk as follows:

a) The MDP (Management Development Program) program, which is a program implemented by recruiting employees who are up to 25 years old and have the ability and skills to use technology. These employees are then expected to be able to share knowledge and teach existing employees, especially employees who are less able to use technology.

b) The implementation of employee recruitment using technology and applications has been running for about 90 percent such as online psychology tests, virtual interviews with video calls.

c) Implementation of virtual training and e-learning-based training that began during the COVID-19 pandemic.

d) Supervision by digitizing HR with the aim of reducing paper use in terms of filing for leave, permits, booking official trips, booking vehicles and using digital attendance with a system developed by the company.

e) Supervision by using an application system installed in each computer or management division in the form of a chip.

f) Using an integrated system through SAP in the production process so that work becomes more effective and efficient. 
3) The process of developing human resources at the PT Pan Brothers, Tbk company during the pandemic was still carried out even though there were changes in the human resource development process mechanism.

4) Integration in the company PT Pan Brothers, Tbk because it has an impact on employee loyalty, especially in difficult situations during the pandemic. This integration should be carried out by every element of the company from top management, middle management, and also low management considering that each element has its own importance in carrying out its duties and functions in the company. Therefore, it requires professional leadership and coordination within the company in leading the team so that the resulting policies do not overlap.

\section{BIBLIOGRAPHY}

AA, A. P. M. (2006). Perencanaan dan Pengembangan Sumber Daya Manusia (p. 95). Bandung: Refika Aditama.

Abbas, W. A. F. (2019). Strategi Pengembangan SDM dalam Persaingan Bisnis Industri Kreatif di Era Digital. ADLIYA: Jurnal Hukum Dan Kemanusiaan, 13(1), 115-126.

Afifuddin. (2015). Dasar-Dasar Manajemen. Alfabeta: Bandung.

Afriansyah, E. A. (2016). Penggunaan Software ATLAS.ti Sebagai Alat Bantu Proses Analisis Data Kualitatif. Mosharafa: Jurnal Pendidikan Matematika, 5(2), 53-63.

Armstrong, M. ; T. (2014). Human Resource Management Practice by Kogan Page Limited (13th ed.). Amherst Massachusetts: HRD Press.

Armstrong, M. (2006). Strategic Human Resource Management-A Guide to Action 3rd Ed.

Badan Pusat Statistik Provinsi Bali. (2019). Badan Pusat Statistik Provinsi Bali. bali.bps.go.id

Bahri, S., \& Arafah, N. (2020). Analisis Manajemen SDM Dalam Mengembangkan Strategi Pembelajaran Di Era New Normal. Tafkir: Interdisciplinary Journal of Islamic Education, 1(1), 20-40.

Brewster, C., Houldsworth, E., Sparrow, P., \& Vernon, G. (2016). International Human Resource Management. Kogan Page Publishers.

Bukit, B., Malusa, T., \& Rahmat, A. (2017). Pengembangan Sumber Daya Manusia. Yogyakarta: Zahir Publishing.

Cascio, W. F. (2013). Managing Human Resources: Prodictivity, Quality of Work Life, Profits (9th ed.). New York: Mc Graw Hill.

Desra. (2019). 6 Strategi Perusahaan Menghadapi Era Revolusi Industri 4.0. https://www.jurnal.id/id/blog/6-strategi-perusahaan-menghadapi-era-revolusi-industri-4-0/

Desy Selviany. (2020). Tangkal Corona Pan Brothers Produksi Masker Kain Yang Bisa Dicuci Hingga 30 Kali.

https://www.tribunnews.com/bisnis/2020/04/25/tangkal-corona-pan-brothers-produksi-maskerkain-yang-bisa-dicuci-hingga-30-kali

E. Cahyono. (2020). Revolusi Industri 4.0 dan Transformasi Organisasi Pemerintah. http://setkab.go.id/revolusi-industri-4-4-dan-transformasiorganisasipemerint/

Fadhil, R., Maarif, M. S., Bantacut, T., \& Hermawan, A. (2017). Model Strategi Pengembangan Sumber Daya Manusia Agroindustri Kopi Gayo dalam Menghadapi Masyarakat Ekonomi ASEAN. Journal of Technology Management, 16(2), 141-155.

Farchan, F. (2018). Strategi MSDM: Sebuah Cara Menciptakan Kinerja Organisasi dalam Mencapai Keunggulan Bersaing. Risâlah, Jurnal Pendidikan Dan Studi Islam, 4(1, March), 42-52.

Fatkhuri, F. (2020). The COVID-19 Pandemic and The Challenges of State Capacity in Education Policy. Global Komunika: Jurnal Ilmu Sosial Dan Ilmu Politik, 1(3), 1-10.

Firmansyah, M. A., \& Mahardhika, B. W. (2018). Pengantar Manajemen. Deepublish. 
Friese, S. (2014). Qualitative Data Analysis with ATLAS.ti (2nd ed.). SAGE Publications.

Gary, D. (2007). Manajemen Sumber Daya Manusia (Jilid 2). Prenhalindo: Jakarta.

Google.com. (2020). Perubahan Harian Kasus COVID-19.

https://www.google.com/search?q=jumlah+kasus+virus+corona+di+indonesia+per+tanggal+28+ september+2020\&oq=jumlah+kasus+\&aqs=chrome.1.69i57j35i39j0i131i433j0i131i395i433j0i3 95i433j0i395j0i131i395i43312j0i395i433j0i131i395i433.6351j1j7\&sourceid=chrome\&ie=UTF8

Hamidi. (2008). Metode Penelitian Kualitatif. UMM Press: Malang.

Hanif Gusman. (2020). Bagaimana Pandemi COVID-19 Memengaruhi Angka Pengangguran RI. https://tirto.id/bagaimana-pandemi-covid-19-memengaruhi-angka-pengangguran-ri-fK3e

Haryono, S. (2018). Re-Orientasi Pengembangan Sdm Era Digital Pada Revolusi Industri 4.0: The National Conference on Management and Business (NCMAB). Direktorat Pascasarjana Universitas Muhammadiyah Yogyakarta.

Hasibuan, M. S. P. (2016). Manajemen Sumber Daya Manusia. Bumi Aksara.

Hendriyaldi, H., \& Mailindra, W. (2019). Revolusi Industri 4.0: Tantangan dan Peluang Manajemen Sumber Daya Manusia Untuk Meningkatkan Produktivitas Grand Hotel Jambi. Procuratio: Jurnal Ilmiah Manajemen, 7(3), 344-351.

HMS, I., \& Priyono. (2014). Penelitian Kualitatif di Manajemen dan Bisnis. ZIFATAMA.

Institut Pertanian Bogor. (2020). Business Talk Series: Talent Management oleh Syamsul Maarif dan Achmad Ardianto. http://sb.ipb.ac.id/id/manajemen-sdm-era-covid-19/

International Labour Organization (ILO). (2020). Dalam Menghadapi Pandemi: Memastikan Keselamatan dan Kesehatan di Tempat Kerja.

Kamus Besar Bahasa Indonesia. (2020). Kamus Besar Bahasa Indonesia. https://kbbi.web.id/

Kramar, R., Bartram, T. K., Gerhart, B. A., Hollenbeck, J. R., Noe, R. A., \& Wright, P. M. (2014). Human Resource Management: Strategy, People, Performance. McGraw-Hill Education New York.

Leski Rizkinaswara. (2020). Revolusi Industri 4.0. https://aptika.kominfo.go.id/2020/01/revolusi-industri-4-0/

Li, K., Liu, X., Mai, F., \& Zhang, T. (2020). The Role Of Corporate Culture In Bad Times: Evidence From The Covid-19 Pandemic. Available at SSRN 3632395.

M. Reza Sulaiman dan Luthfi Khairul Fikri. (2020). Hindari Bangkrut Ini Strategi Perusahaan Hindari Phk Massal Saat Pandemi.

https://www.suara.com/lifestyle/2020/09/19/105647/hindari-bangkrut-ini-strategi-perusahaanhindari-phk-massal-saat-pandemi?page $=$ all

Machado, C. (2018). Organizational Behaviour and Human Resource Management: A Guide to a Specialized MBA Course. Springer.

Martono, K. T., \& Rahman, A. Z. (2020). Pelatihan Teknologi Cloud Computing dalam Proses Rekrutmen Pegawai pada Masa Pandemi Covid 19. Seminar Nasional Pengabdian Kepada Masyarakat UNDIP 2020, 1(1).

Mathis, R. L., \& Jackson, J. H. (2011). Manajemen Sumber Daya Manusia. Jakarta: Salemba Empat.

Moleong, L. J. (2017). Metodologi Penelitian Kualitatif, Edisi Revisi. Bandung: PT. Remaja Rosda Karya.

Mu'ah, M. (2015). Manajemen Sumber Daya Manusia. Sidoarjo: Zifatama.

Mu'ah, M. (2017). Manajemen Sumber Daya Manusia Profesional. Sidoarjo: Zifatama Publisher.

Muhamad Ali. (2020). Menata SDM Pasca - Pandemi Menuju New Normal. https://nasional.sindonews.com/read/37699/18/menata-sdm-pasca-pandemi-menuju-newnormal-1589907946

Mungkasa, O. (2020). Bekerja dari Rumah (Working From Home/WFH): Menuju Tatanan Baru Era Pandemi COVID 19. Jurnal Perencanaan Pembangunan: The Indonesian Journal of Development Planning, 4(2), 126-150.

Ngadi, N., Meliana, R., \& Purba, Y. A. (2020). Dampak Pandemi Covid-19 Terhadap Phk Dan Pendapatan Pekerja Di Indonesia. Jurnal Kependudukan Indonesia, 43-48.

Nurhadi Pratomo. (2020). Pan Brothers (PBRX) Pede Kinerja 2020 Lebih Baik dari 2019. 
https://market.bisnis.com/read/20200707/192/1262880/pan-brothers-pbrx-pede-kinerja-2020lebih-baik-dari-2019

Ong, J. O., \& Mahazan, M. (2020). Strategi Pengelolaan SDM dalam Peningkatan Kinerja Perusahaan Berkelanjutan di Era Industri 4.0. Business Economic, Communication, and Social Sciences (BECOSS) Journal, 2(1), 159-168.

Pangestuti, D. C. (2019). Analisis Pengalaman Kerja, Kompetensi, Pendidikan dan Pelatihan Terhadap Pengembangan Karir dengan Intervening Prestasi Kerja. Jurnal Riset Manajemen Dan Bisnis (JRMB) Fakultas Ekonomi UNIAT, 4(1), 57-68.

Petrus Dabu. (2020). Adaptasi, Kunci Pan Brothers Tbk Tetap Rekrut Karyawan di Tengah Pandemi 2020. http://www.theiconomics.com/art-of-\%09execution/adaptasi-kunci-pan-brothers-tbktetap-rekrut-karyawan-di-tengah-pandemi/

Priyono, M. (2014). Manajemen Sumber Daya Manusia. Zifatama Publisher: Sidoarjo.

Prof. Dr. Wibowo. (2017). Manajemen Sumber Daya Manusia, Edisi Revisi. Surabaya: CV R.A.De.Rozarie.

PT Pan Brothers Tbk. (2020). Laporan Tahunan PT. Pan Brothers, Tbk Tahun 2019. https://www.panbrotherstbk.com/uploads/PBRX_ANNUAL REPORT 2019.pdf

Raco, J. (2018). Metode Penelitian Kualitatif: Jenis, Karakteristik dan Keunggulannya.

Ramly, A. T., \& Syukur, D. A. (2017). Strategic Management of Organization Development and Civil Service Based PumpingHR Model at Ibn Khaldun University Bogor.

Ria Theresia. (2020). Dampak Covid-19 Minim, Penjualan Ekspor Pan Brothers (PBRX) Tetap Solid. https://market.bisnis.com/read/20200511/192/1239013/dampak-covid-19-minim-\%09penjualanekspor-pan-brothers-pbrx-tetap-solid

Rifa'i, M., \& Wijaya, C. (2016). Dasar-Dasar Manajemen. Medan: Perdana Publishin.

Schaar, A. K., Calero Valdez, A., Hamann, T., \& Ziefle, M. (2019). Industry 4.0 and its future staff. Matching millennials perceptions of a perfect job with the requirements of digitalization. 7th International Conference on Competitive Manufacturing (COMA 2019), Stellenbosch, South Africa, 246-252.

Schuller; Randall; Susan E. Jacson. (2016). Manajemen Sumber Daya Manusia (Terjemahan: Nurdin Sobari). Erlangga, Jakarta.

Shamim, S., Cang, S., Yu, H., \& Li, Y. (2016). Management Approaches for Industry 4.0: A Human Resource Management Perspective. 2016 IEEE Congress on Evolutionary Computation (CEC), 5309-5316.

Sugiyono. (2014). Metode Penelitian Kuantitatif Kualitatif dan R\&D. Alfabeta, Bandung.

Sugiyono. (2016). Metode Penelitian Kuantitatif Kualitatif dan R\&D. Alfabeta, Bandung.

Sumardjo, Mahendro, \& Priansa, D. J. (2018). Manajemen Pengembangan Sumber Daya Manusia: Konsep-Konsep Kunci. Cetakan Pertama. Penerbit Alfabeta. Bandung.

Sumardjo, Mahendro. (2011). Pengaruh Penilaian Kinerja, Pengembangan SDM, Kompetensi, dan Komitmen Organisasional Terhadap Produktivitas Kerja (Survei pada Auditor di Badan Pemeriksa Keuangan Republik Indonesia). Strategic: Jurnal Pendidikan Manajemen Bisnis, $11(1), 1-16$.

Sunarto, A. (2020). Pengembangan Sumber Daya Manusia dengan Berbasis Inovasi Untuk Menghadapi Revolusi Industri 4.0. Jurnal Ilmiah MEA (Manajemen, Ekonomi, \& Akuntansi), 4(2), 397-407.

Sutrisno, E. (2011). Manajemen Sumber Daya Manusia, Cetakan Kelima. Jakarta: Kencana Prenada Media Group.

Suwatno, H., \& Priansa, D. J. (2011). Manajemen SDM dalam Organisasi Publik dan Bisnis. Bandung: Alfabeta.

Thajono. (2019). Manajemen Sumber Daya Manusia. Yogyakarta: Visi Solusi Madani.

Tribunnews.com. (2018). Pemerintah Ajak Industri Antisipasi Tantangan Ketenagakerjaan Revolusi Industri 4.0. https://www.tribunnews.com/kilas-kementerian/2018/11/26/pemerintah-ajakindustri-antisipasi-tantangan-ketenagakerjaan-revolusi-industri-40

Vina Anggita. (2020a). Pan Brothers Berlakukan Dua Shift Kerja Demi Hindari Potensi Covid-19. https://swa.co.id/covid19/pan-brothers-berlakukan-dua-shift-kerja-demi-hindari-potensi-covid- 
19

Vina Anggita. (2020b). Penting Bagi Perusahaan Kembangkan Skill Karyawan Di Tengah Pandemi. https://swa.co.id/swa/trends/penting-bagi-perusahaan-kembangkan-skill-karyawan-di-tengahpandemi

Wahyuningsih, S. (2013). Metode Penelitian Studi Kasus: Konsep, Teori Pendekatan Psikologi Komunikasi, dan Contoh Penelitiannya. Madura: UTM Press. Dalam Https://Www. Scribd. Com/Document/3824, 91045.

Wali, A. I., Omar, S. O., \& Sadq, Z. M. (2016). The Role of Human Resource Development Strategies on Capabilities of Strategic Innovation (An Empirical Study at Akre Technical Institute/Kurdistan Region-Iraq). INTERNATIONAL JOURNAL, 3(1).

Wardini K.A. (2018). Human Capital dan Keunggulan Bersaing di Era Revolusi Industri 4.0. www.ut.ac.id

Wiji Nurhayat. (2020). Tantangan dan Strategi HR Hadapi New Normal saat Pandemi COVID19.https://www.talenta.co/blog/administrasi-hr/tantangan-dan-strategi-hr-hadapi-new-normalsaat-pandemi-covid-19/

Wijonarko, G., Aribowo, H., Winarto, A., \& Ramadoni, W. (2020). Perancangan Program Pelatihan Karyawan Dalam Rangka Mendukung Produktivitas Karyawan di Masa Pandemi COVID 19. JURNAL EKSEKUTIF, 17(1).

World Health Organization (WHO). (2020). World Health Organization. who.int

Yanuar Riezqi Yovanda. (2020). Bos Pan Brothers Sebut Pandemi Covid-19 Butuh Kegigihan Tenaga Kerja, 2020.

https://www.tribunnews.com/bisnis/2020/09/18/bos-pan-brothers-sebut-pandemi-covid-19-

butuh-kegigihan-tenaga-kerja

Yawson, R. (2020). Strategic Flexibility Analysis Of Hrd Research And Practice Post Covid-19 Pandemic. Human Resource Development International, 23(4), 406-417.

Yusuf, M. (2019). Strategi Manajemen Perubahan Pola Pikir SDM Guna Menghadapi Persaingan Era Industri 4.0 Pada Industri Manufaktur.

Yusuf, Muri. (2017). Metode Penlitian Kuantitafif, Kualitatif \& Penelitian Gabungan. In Jakarta: Kencana. 